\title{
Welfare cannot be made to go away
}

\author{
Most governments have taken fright at the growing cost of welfare and, perhaps inevitably during a recession, are \\ canvassing mean devices for containing costs. But welfare is inescapable in a modern state.
}

FORTY per cent of the British government's budget goes on welfare in various forms, from free medical care through the National Health Service to pensions for the elderly and unemployment pay for those who have lost their jobs. It is much the same in the United States, where what are called 'entitlements' mount inexorably from year to year and where the new president's wife, Mrs Hillary Rodham Clinton, is saddled with responsibility for making health care accessible to all. The same is true of France and Germany (where the cost of medical care, mostly covered by 'insurance', is 8.7 per cent of gross domestic product). Then in Scandinavia in the past few years, governments have been chipping away at what was once the most generous welfare system in the world: tax rates became uncompetitively high. What paradox ensures that the cost of welfare comes to seem insupportable in the best-off communities? And what will persuade them that the seeming paradox is not a paradox at all?

The first principle is one that has been amply demonstrated in the past two centuries by the experience of the now-industrialized countries of the world (Japan excepted): civility, and in particular seemly relations between rich and relatively poor, require that the very poor should have food and shelter and should not die when medicine might save them. Moreover, given that even the best-intentioned charities are necessarily idiosyncratic, it is proper that the source of welfare should be government, usually central but sometimes regional or even local. That rich communities find the burden of welfare heaviest is then no surprise, for the cost of relieving poverty is not an absolute sum, but one that necessarily increases with general prosperity. To know that, it is sufficient to observe that in many poor countries, too poor to afford welfare programmes, the majority of the population might be held eligible in Europe or North America.

The second principle is that, although welfare is rightly financed and administered by governments, no particular scheme of benefits (in Britain) or entitlements (in the United States) should be regarded as a right. The essential is merely that all eligible people should be dealt with on an equal footing. But what is then to be made of the pensions paid to elderly people, who may claim that the payments they are compelled to contribute during their working lives should be compared to insurance premiums that earn them a pension when they cease to work? That belief attaches notably to the Social Security system in the United States, partly because of the way in which contributions are notionally added to an identifiable fund whose adequacy is regularly assessed by actuaries. Mystifyingly, social security pensions are also free from tax, which fosters the illusion that they are something special. But the belief is a myth. Pensions are, or should be, what a sympathetic government calculates to be necessary to keep the poorest old people in seemly comfort; they should be paid to everybody, but should be taxable as a matter of course.

Governments should not be surprised that the cost of medical care is increasingly alarming. Having willed the technology of longevity (by the research they sponsor), governments can hardly complain that the fruits of their success are too expensive. What the National Health Service has done for the civility of British life over nearly half a century is to show that the very young and the very old need not be disadvantaged by circumstances, and that the chronically sick can similarly be helped to a seemly way of life. The social benefits are incalculable (but somebody should nevertheless try to calculate them). The British system also shows that ordinarily healthy and particularly middle-class people are best able to win what they need from the health services. (By comparison, the psychiatrically disabled are awkward customers.) Mrs Clinton's best solution would thus be an extension of the Medicare and Medicaid schemes to cover the 30 million or so uninsured people in the United States - coupled with the cancellation of tax exemption for health insurance premiums.

But does not welfare engender dependence, undermining people's will to fend for themselves? The hypothesis may be correct, but the answer is not to abandon welfare nor to impede access to it. The potentially more constructive solution of giving people skills that will help them to find jobs has been found, in British experience, to be difficult and expensive to arrange - and, in the middle of a recession, ineffective. The idea that welfare recipients might be required to work at social tasks that otherwise would not be done is more appealing, but even more difficult to arrange. Despite schemes called 'workfare' in the United States (in Arkansas, among other states), enthusiasm for this solution should be tempered by the knowledge that a non-job can be as dispiriting as no job. So, while governments have some room in which to manoeuvre (by acting as monopoly purchasers of some services, for example), most had better learn to live with the notion that welfare has come to stay. 